\title{
EFFECT OF LONG-TERM GREEN TEA EXTRACT SUPPLEMENTATION ON PERIPHERAL BLOOD LEUKOCYTES IN CROSSFIT-TRAINED AND UNTRAINED MEN
}

\author{
Agata Żak, ${ }^{1, B, E}$ llona Pokora $2, A, C, D, E$ \\ ${ }^{1}$ The Doctorial Studies, The Jerzy Kukuczka Academy of Physical Education, Katowice, Poland \\ 2 Department of Physiology, The Jerzy Kukuczka Academy of Physical Education, Katowice, Poland

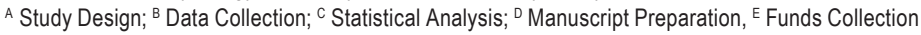

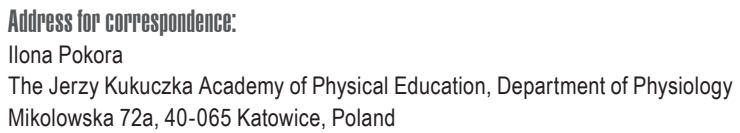

\begin{abstract}
Ahstract The aim of the study was to evaluate the effects of long-term green tea extract (GTE) supplementation on white blood cells (WBC) in CrossFit-trained and untrained men.

Twenty-eight men were recruited for this study including CrossFit-trained (CF-TR) and untrained (CF-UNT) men. The study was carried out in two phases. Phase 1 involved non-supplemented untrained and trained men. Phase 2 involved the same groups but after 6 -week supplementation with 2 GTE capsules once daily. Body weight, body composition and the number and percentage of peripheral blood leukocyte populations were assessed in each phase. The results revealed that the long-term green tea supplementation did not have a significant effect on body weight, body composition and the total white blood cell count of the study participants. However, the percentage of peripheral blood eosinophils increased while monocyte and neutrophil counts decreased. The changes in white blood cells were less pronounced in CrossFit-trained compared to control participants. Summing up, it should be noted that long-term GTE supplementation in CrossFit-trained men did not result in significant changes in body weight and composition and the total white blood cell count. However, the changes in leukocyte subsets were less pronounced in CrossFit-trained compared to untrained participants.
\end{abstract}

Key WOrls supplementation, green tea, leukocytes, physical training, CrossFit

\section{Introduction}

Leukocytes also referred to as white blood cells (WBC) are the mobile units of the body's protective system. Six types of white blood cells are normally found in the blood: $(62 \%)$ neutrophils, $(2.3 \%)$ eosinophils, $(0.4 \%)$ basophils, (5.3\%) monocytes and (30\%) lymphocytes (Vattem, Maitin, 2016). Although leukocyte subpopulations differ in counts, all of them play a significant role in the immune defense. The granulocytes and monocytes protect the body against invading organisms, whereas the lymphocytes function mainly in connection with the immune system. 
For the past 15 years a considerable amount of research has been carried out regarding the effect of polyphenols from unfermented green tea leaves on human health and functions of the immunology system (Mizolf, Szymusiak, Wiglo, Reitjers, Tyrakowska, 2008; Bayer, Jansen, Beltz, 2012). Green tea contains polyphenols of the flavanol and flavonoid groups, proanthocyanidins and phenolic acids, which make up to $30 \%$ of fresh leaf dry weight (McKay, Blumberg, 2002). The main green tea polyphenols are catechins including epicatechin (EC), epicatechin gallate (ECG), epigallocatechin (EGC) and epigallocatechin-3-gallate (EGCG). The latter has potent anti-inflammatory (Dona et al., 2003), antibacterial and antiproliferative (Osada et al., 2001; Saleh, Raghupathy, Asfar, Oteifa, Al-Saleh, 2014), antimutagenic and cytoprotective actions (Zhu et al., 2014). The primary targets of the anti-inflammatory compounds are the inhibition of inflammatory cell recruitment and proinflammatory mediator production. EGCG reduces neutrophil and monocyte migration through capillary membranes towards chemoattractants (Qin et al., 2011; Pae, Wu, 2013) and monocyte attachment to vascular endothelium (Ludwig et al., 2004; Takano, Tanaka, Aoi, Yahagi, Fushiya, 2004; Han, Toborek, Hennig, 2012). Catechins also inhibit proinflammatory cytokine production and decrease the activity of neutrophil elastase and ROS production. Through increasing a total plasma antioxidant capacity green tea catehins, may prevent cells from reactive oxygen species (ROS) damage (Benzie, Szeto, Strain, 1999; Yin, Tang, Su, 2008), however an increase in antioxidant activity was recorded with increase $\mathrm{pH}$ of the surrounding medium or tissues (Mizolf et al., 2008). Orally administrated EGCG and green tea extract block neutrophil-mediated angiogenesis in vivo in an inflammatory angiogenesis model (Dona et al., 2003).

Physical activity induces changes in leukocyte number and functions (Walsh et al., 2011; Orysiak, Witek, Żmijewski, Gajewski, 2012). The magnitude and directions of these changes depend on the duration, intensity and type of exercise (Hulmi et al., 2010). The total number of white blood cells, lymphocytes and neutrophils increase during exercise and decrease below resting values immediately after cessation of the exercise (Pyne, Gleeson, 1998; Horn, Pyne, Hopkins, Barnes, 2010). It is believed that postexercise lymphopenia and neutropenia may result from two parallel processes, i.e., increased migration of lymphocytes and neutrophils to surrounding tissues and enhanced apoptosis (Mooren et al., 2012). The effect of these processes on the relative and absolute postexercise WBC counts depends on concomitant hormonal changes, growth factors, blood oxidative status and adaptation to exercise. On the other hand, regular exercise and physical training cause a change in the immune functions and the mobility of leukocytes, depending on the training characteristics and fitness level (Natale et al., 2003; Mooren, Lechtermann, Völker, 2004; Gleeson, 2007).

CrossFit is a popular training modality which involves a variety of high-intensity functional movements within a "Grace", "Cindy" or "Fran" workout of short duration (<30 min) but large volume (Kliszczewicz et al., 2015). It produces pronounced responses within the circulatory and endocrine systems; it also alters aerobic and anaerobic capacity and postexercise leukocyte counts in the peripheral blood (Pokora, Żak, Pokora, 2015).

Considering an important role of white blood cells in the body's defense system against invading organisms, exercise-induced a temporary depression of various aspects of immune functions and the beneficial influence of green tea compounds on the immune system, the aim of the current study was to evaluate the effects of long-term green tea supplementation (GTE) on the total number of white blood cells and leukocyte subsets in CrossFit-trained and untrained men. To conduct this analysis, we used blood samples that we collected before and after 6-weeks GTE supplementation in CrossFit trained and untrained men. We hypothesized that compared with untrained men, GTE supplementation in CrossFit trained men may attenuate a reduction of leukocyte counts during training. 


\section{Methods}

Twenty-eight men were recruited: a group of CrossFit-trained men (CF-TR) and a group of students of the Academy of Physical Education who regularly participated in mandatory physical exercise courses but not CrossFit training (CF-UNT). The subjects were informed of the aims and methods of the study and gave written consent to participate; they were also informed about the right to withdraw consent to participate at any time without giving reasons. The research project was approved by the Bioethics Committee of the Jerzy Kukuczka Academy of Physical Education in Katowice.

Prior to the study body weight and composition were measured using a body composition analyzer an with an 8-point tactile electrode system (InBody 220, Biospace, Korea) and a gas analyser (MetaLyzer 3B-2R, Cortex, Germany) was used to determine level of physical fitness (maximal oxygen uptake; $\mathrm{VO}_{2 \mathrm{max}}$ ). $\mathrm{VO}_{2}$ max was determined in both study groups during a graded intensity exercise test performed until exhaustion (GXT); (Howley, Bassett, Welch, 1995).

A proper study was carried out in two phases. Phase 1 involved non-supplemented untrained and trained men. Phase 2 involved the same groups but after 6 -week supplementation with GTE. Once daily (during a 6 -week supplementation period), each participant ingested two $250 \mathrm{mg}$ capsules of OLIMP Green Tea Extract (55\% EGCG), a dose equivalent to $275 \mathrm{mg}$ EGCG, $498 \mathrm{mg}$ polyphenols and $400 \mathrm{mg}$ catechins were administrated orally. During a 6 -week supplementation period the participants attended CrossFit training sessions or regular exercise courses at the Academy of Physical Education.

Prior to and after GTE supplementation blood samples were collected in each group. The fasting blood samples were collected from an antecubital vein. One milliliter of blood sample was immediately transferred into a special container containing anticoagulant (heparin, $75 \mathrm{U} / \mathrm{ml}$ ) for WBC count. The Sysmex-2100 Automated Hematology System (Roche, Poland) was used to determine: white blood cell count and the leukocyte subsets: neutrophil, lymphocyte, monocyte, eosinophil and basophil counts in the taken blood samples.

Statistical analysis was performed using the STATISTICA 10.0 (StatSoft, Poland). Before statistical analysis, all data were checked to determine if they were normally distributed. Normally distributed blood data were analysed using one way repeated-measures ANOVA to calculate the main effects of time (supplementation) and time $x$ trial interaction. When a significant main effect was evident $(p<0.05)$, post hoc Tukey's tests were used to compare changes over time and differences between the trials. Normally distributed data are presented as mean \pm SD. Data that were not normally distributed (eosinophile cell counts) were analysed using $U$ test followed by Wilcoxon's signed-ranked tests to compare changes over time and differences between the trials. Non normally distributed data are presented as median \pm interquartile range. The Student's t test (independent samples) was used to verify differences between the subject's characteristics.

\section{Results}

The anthropometric characteristics and $\mathrm{VO}_{2}$ max of both study groups are presented in Table 1.

No statistically significant differences were revealed with respect to body weight and composition between CrossFit-trained men and non-trained students. However, the two groups differed significantly regarding the maximal oxygen uptake (Table 1). 
Table 1. Characteristics of the study participants

\begin{tabular}{|c|c|c|c|}
\hline & $\begin{array}{l}\text { CF-TR } \\
\text { group }\end{array}$ & Differences & $\begin{array}{c}\text { CF-UNT } \\
\text { group }\end{array}$ \\
\hline$N=$ & 20 & & 9 \\
\hline Age (years) & $24.17 \pm 2.53$ & & $24.14 \pm 1.06$ \\
\hline $\mathrm{BH}(\mathrm{cm})$ & $180.25 \pm 5.31$ & & $180.57 \pm 4.03$ \\
\hline BW (kg) & $80.25 \pm 7.68$ & & $77.5 \pm 3.56$ \\
\hline$\% \mathrm{BF}$ & $14.27 \pm 4.01$ & & $11.7 \pm 2.91$ \\
\hline $\mathrm{VO}_{2} \max \left(\mathrm{L} \cdot \mathrm{min}^{-1}\right)$ & $3.55 \pm 0.55$ & * & $4.28 \pm 0.36$ \\
\hline $\mathrm{VO}_{2} \max \left(\mathrm{ml} \cdot \mathrm{kg}^{-1} \cdot \mathrm{min}^{-1}\right)$ & $44.41 \pm 5.24$ & ** & $55.48 \pm 6.09$ \\
\hline
\end{tabular}

The data are presented as means and standard deviations $( \pm \mathrm{SD})$; body height -BH; body weight -BW; body fat percentage - \% BF; maximal oxygen uptake $\mathrm{VO}_{2} \max ;{ }^{*} p<0.05 ;{ }^{* *} p<0.01$.

Resting leukocyte, neutrophil, lymphocyte, monocyte, eosinophil and basophil counts were within normal, physiological ranges (Table 2, Figures 1 and 2) and did not differ significantly between the groups before and after GTE supplementation. However, the total white blood cell count as well as neutrophil and monocyte counts were reduced while the number of eosinophils increased after GTE administration in both study groups.

Table 2. CrossFit-trained men (CF-TR) - changes in the number and percentage of particular leukocyte populations expressed as absolute $\left(x 10^{9} / L\right)$ and percentage values before and after GTE supplementation $\left({ }^{*} p<0.05\right)$

\begin{tabular}{|c|c|c|c|c|c|}
\hline & $\begin{array}{c}\text { Neutrophils } \\
{\left[\times 10^{\%} / \mathrm{L}\right]}\end{array}$ & $\begin{array}{c}\text { Lymphocytes } \\
{\left[\times 10^{\circ} / \mathrm{L}\right]}\end{array}$ & $\begin{array}{c}\text { Monocytes } \\
{\left[\times 10^{\circ} / \mathrm{L}\right]}\end{array}$ & $\begin{array}{c}\text { Eosinophils } \\
{\left[\times 10^{9} / \mathrm{L}\right]}\end{array}$ & $\begin{array}{l}\text { Basophils } \\
{\left[\times 10^{\%} / \mathrm{L}\right]}\end{array}$ \\
\hline PRE suppl & $3.31 \pm 1.19$ & $2.18 \pm 0.54$ & $0.66 \pm 0.18$ & $0.1<0.07-0.3>$ & $0.03 \pm 0.02$ \\
\hline AFTER suppl & $3.14 \pm 1.95$ & $2.22 \pm 0.31$ & $0.63 \pm 0.07$ & $0.12<0.08-0.3>$ & $0.03 \pm 0.01$ \\
\hline \multirow[t]{2}{*}{$\Delta[\%]$} & -5.45 & 1.80 & -5.70 & $+20.0^{*}$ & \\
\hline & $\begin{array}{c}\text { Neutrophils } \\
{[\%]}\end{array}$ & $\begin{array}{c}\text { Lymphocytes } \\
{[\%]}\end{array}$ & $\begin{array}{c}\text { Monocytes } \\
{[\%]}\end{array}$ & $\begin{array}{c}\text { Eosinophils } \\
{[\%]}\end{array}$ & $\begin{array}{c}\text { Basophils } \\
{[\%]}\end{array}$ \\
\hline PRE suppl & $50.66 \pm 8.18$ & $35.42 \pm 7.29$ & $10.71 \pm 2.5$ & $1.17<1.1-3.7>$ & $0.48 \pm 0.22$ \\
\hline AFTER suppl & $49.78 \pm 9.48$ & $36.46 \pm 7.77$ & $10.27 \pm 3.32$ & $2.2<1.5-3.6>$ & $0.44 \pm 0.14$ \\
\hline$\Delta[\%]$ & -1.76 & 2.85 & -4.27 & $+29.0^{*}$ & -8.86 \\
\hline
\end{tabular}

Normally distributed data are presented as mean \pm SD; non normally distributed data (eosinophils) are presented as median $<>$ interquartile range.

Table 3. Untrained participants (CF-UNT) - changes in the number and percentage of particular leukocyte populations expressed as absolute $\left(\times 10^{9} / L\right)$ and percentage values before and after GTE supplementation $\left({ }^{*} p<0.05\right)$

\begin{tabular}{|c|c|c|c|c|c|}
\hline & $\begin{array}{c}\text { Neutrophils } \\
{\left[\times 10^{9} / \mathrm{L}\right]}\end{array}$ & $\begin{array}{c}\text { Lymphocytes } \\
{\left[\times 10^{9} / \mathrm{L}\right]}\end{array}$ & $\begin{array}{c}\text { Monocytes } \\
{\left[\times 10^{9} / L\right]}\end{array}$ & $\begin{array}{c}\text { Eosinophils } \\
{\left[\times 10^{9} / \mathrm{L}\right]}\end{array}$ & $\begin{array}{l}\text { Basophils } \\
{\left[\times 10^{9} / \mathrm{L}\right]}\end{array}$ \\
\hline PRE suppl & $3.21 \pm 2.04$ & $2.04 \pm 0.56$ & $0.58 \pm 0.22$ & $0.13<0.07-0.2>$ & $0.03 \pm 0.016$ \\
\hline AFTER suppl & $2.79 \pm 0.56$ & $1.96 \pm 0.45$ & $0.49 \pm 0.11$ & $0.17<0.12-0.3>$ & $0.024 \pm 0.013$ \\
\hline \multirow[t]{2}{*}{$\Delta[\%]$} & -15.05 & -4.08 & -18.37 & $+31.0^{*}$ & -25.0 \\
\hline & $\begin{array}{c}\text { Neutrophils } \\
{[\%]}\end{array}$ & $\begin{array}{c}\text { Lymphocytes } \\
{[\%]}\end{array}$ & $\begin{array}{c}\text { Monocytes } \\
{[\%]}\end{array}$ & $\begin{array}{c}\text { Eosinophils } \\
{[\%]}\end{array}$ & $\begin{array}{c}\text { Basophils } \\
{[\%]}\end{array}$ \\
\hline PRE suppl & $51.20 \pm 9.18$ & $35.78 \pm 8.29$ & $9.82 \pm 2.26$ & $2.15<1.3-3.9>$ & $0.51 \pm 0.35$ \\
\hline AFTER suppl & $51.16 \pm 3.73$ & $35.61 \pm 3.21$ & $8.94 \pm 1.96$ & $2.97<2.1-5.7>$ & $0.50 \pm 0.33$ \\
\hline$\Delta[\%]$ & -0.08 & -0.47 & -9.84 & $+38.0^{*}$ & -2.0 \\
\hline
\end{tabular}

Normally distributed data are presented as mean \pm SD; non normally distributed data (eosinophils) are presented as median < > interquartile range. 
Six-week GTE supplementation resulted in a statistically significant increase in the absolute eosinophil count in the CF-TR group and an increase in the percentage of eosinophils in the CF-TR and CF-UNT groups (Tables 2 and 3) (Figure 3); however, neither group exhibited eosinophilia (>0.600 x 10\%/L). GTE supplementation caused a decrease in absolute monocyte count and percent monocytes in both study groups (Figure 2).
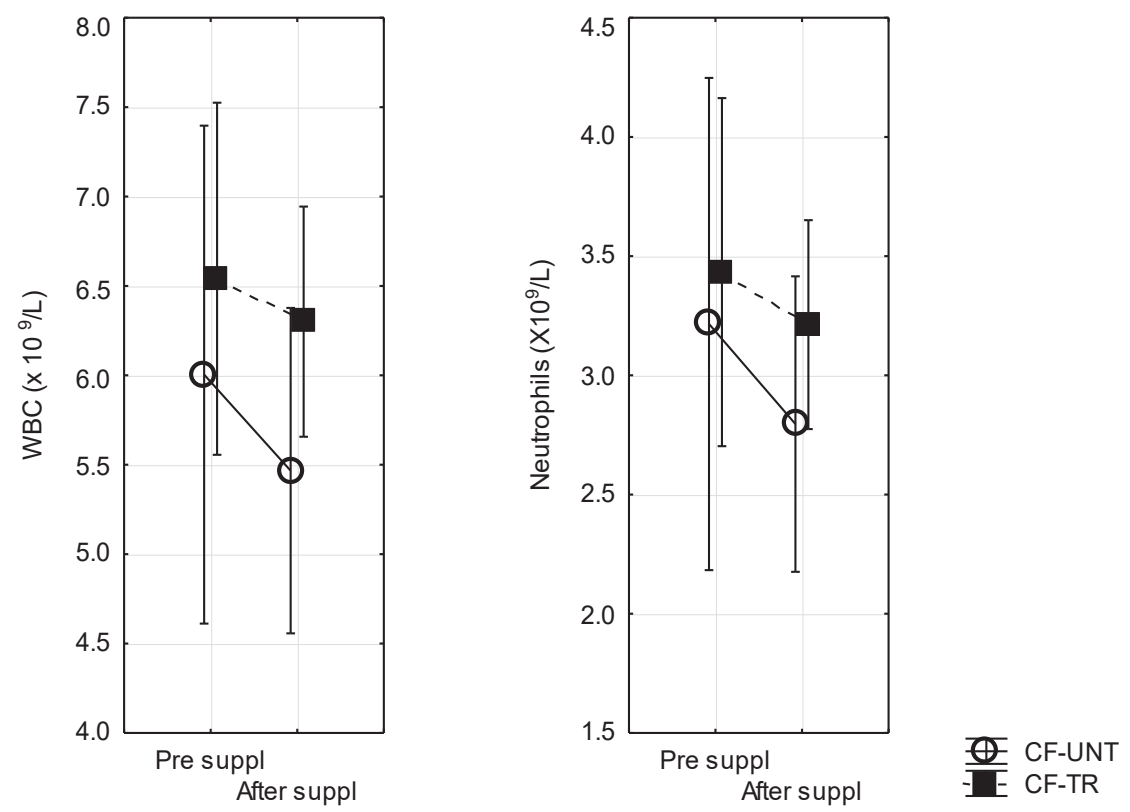

Figule 1. Total white blood cell count and neutrophil count at rest in CrossFit-trained and untrained participants before and after 6-week supplementation with GTE, * $p<0.05$

The change in leukocyte cell counts in response to GTE supplementation was significantly more pronounced in untrained men as evidenced by a larger decrease in absolute monocyte count and a greater increase in absolute eosinophil count and percent eosinophils (Tables 2 and 3 ). 


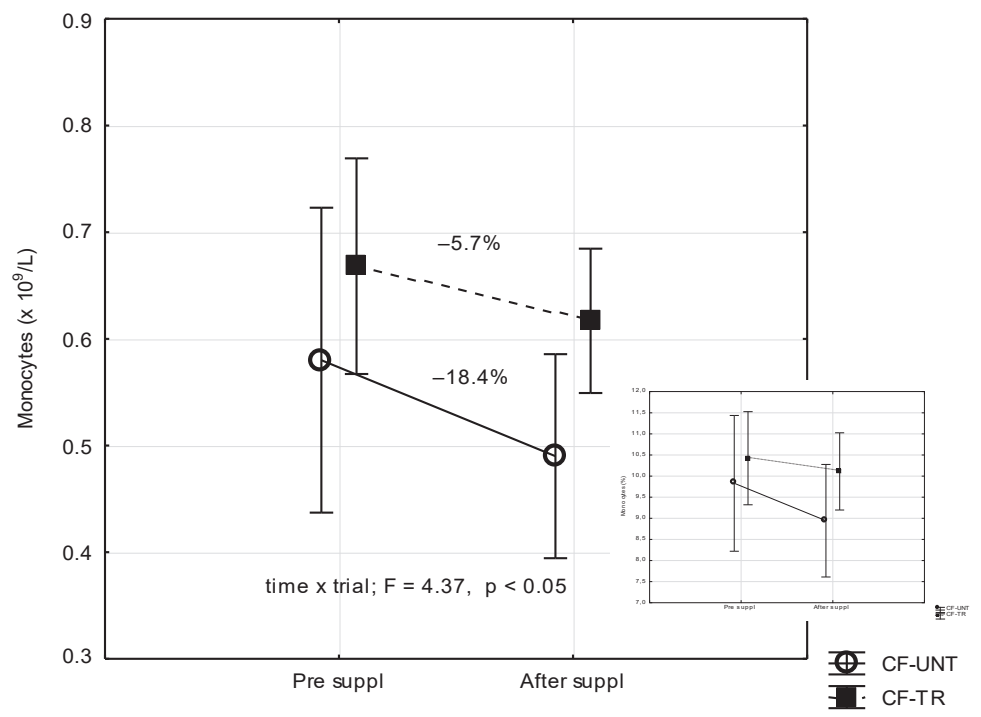

Figure 2. Absolute monocyte count and percent monocytes at rest in untrained (CF-UNT) and CrossFit-trained (CF-TR) men before and after GTE supplementation ( ${ }^{*} p<0.05$ )

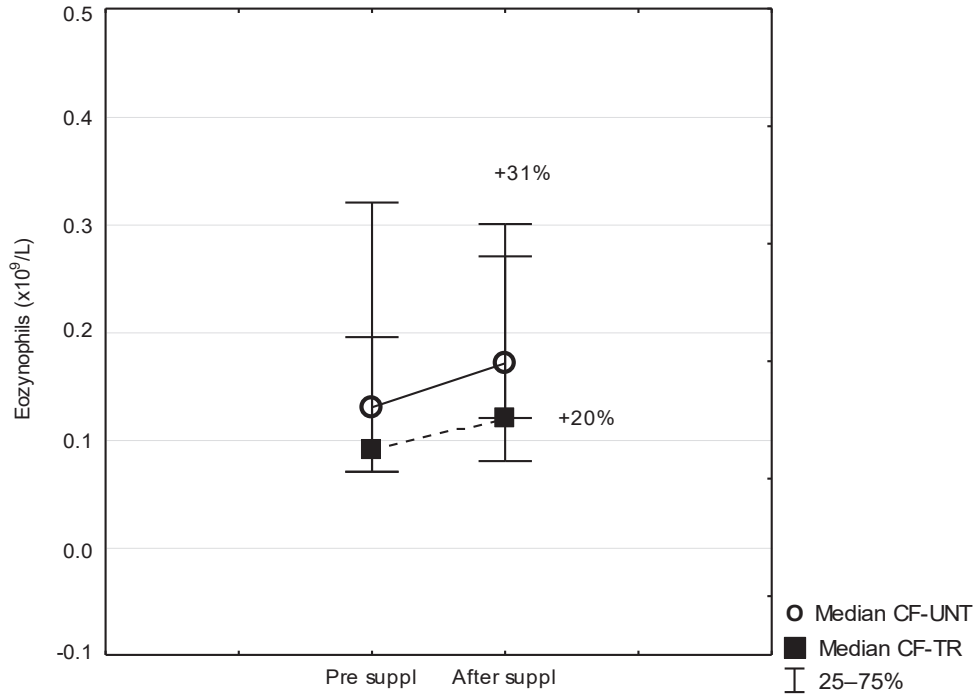

Figure 3. Absolute eosinophil count and percent eosinophils at rest in untrained (CF-UNT) and CrossFit-trained (TR) men before and after GTE supplementation ( ${ }^{*} p<0.05$ ). Data presented as median and interquartile range 


\section{Discussion}

The results of our study revealed that 6 weeks of GTE supplements did not have a significant effect on body weight and body composition of CrossFit-trained and control participants although both groups did differed significantly with respect to $\mathrm{VO}_{2}$ max.

The major finding in this study was that, 6-week GTE supplementation did not influenced on the total WBC number but it had impact on the number and percentage of white blood cell subpopulations in the peripheral blood. Neutrophil and monocyte counts were reduced while the number of eosinophils increased significantly in both study groups. The impact of GTE on the WBC number as well as the percentage of white blood cell subpopulations was more visible in men with higher $\mathrm{VO}_{2}$ max.

Physical activity is typically associated with changes in the concentrations of inflammatory markers, numbers of circulating lymphocytes (Kruger, Mooren, 2014) and the reactivity thereof to exogenous stimuli. Moderately active individuals frequently exhibit a 10\% lower number of WBC compared to sedentary people. Michishita, Shono, Inoue, Tsuruta, Node (2010), found that monocyte and neutrophil counts were correlated with maximal oxygen uptake $\left(\mathrm{VO}_{2} \mathrm{max}\right)$. They also found significant correlations between cardiorespiratory fitness and total leukocyte, monocyte and neutrophil numbers and observed that the numbers were higher in women with low $\mathrm{VO}_{2}$ max compared to those with higher levels of physical fitness. Similar results were reported by Metrikat, Albrecht, Maya-Pelzer, Ortlepp (2009), who analysed the relationships between the concentrations of inflammatory markers and physical fitness in over 10,000 young men. They found that leukocyte numbers were inversely proportional to physical fitness level, i.e., higher level of physical fitness was associated with lower WBC. However, leukocyte reactivity to proapoptotic factors was lower (Kruger, Mooren, 2014).

A decrease in WBC number contributes to susceptibility to infections. In this study GTE supplementation did not have a significant effect on total leukocyte number of our study participants although CrossFit-trained men had higher white blood cell counts compared to untrained participants. Both study groups were in the second quartile $\left(5.8-6.8 \times 10^{\%} / /\right)$ of the WBC reference range for adult males (according to laboratory reference range values).

The 6-week GTE supplementation had an impact on the number and percentage of white blood cell subpopulations. Literature reports indicate that the effect of GTE on the immune system depends on the dose and can either suppress or enhance peripheral blood mononuclear cell proliferation (Qin et al., 2011), (Kim, Quon, Kim, 2014). The effectiveness of GTE supplementation may be related to individual characteristics, age, gender or physical fitness level. Evidence exists that green tea poliphenols may have an antioxidative or pro-oxidative potential. Green tea extract and EGCG exert the pro-oxidative effect in subjects with low baseline oxidative stress, whereas green tea poliphenols may be scavenging ROS in subjects with high baseline oxidative stress. According to Forester and Lambert suggestion, with moderate and low concentrations EGCG, low level oxidative stress may be a beneficial cue for the body to initiate induction of protective anti-oxidant systems and host immune responses (Lambert, Elias, 2010), (Forester, Lambert, 2011). Thus under same (exercise, training) conditions with increased oxidative stress, supplementation of green tea polyphenols may attenuated ROS mediated tissue damage. In addition, EGCG inhibits proinflammatory cytokine and chemokine expression (Dona et al., 2003), decreases the expression of integrins and chemokines (monocyte chemoattractant protein-1) (Majkova, Smart, Toborek, Hennig, 2009), vascular cell adhesion proteins, (Ludwig et al., 2004), (Han et al., 2012), helps lower adhesion and migration of mast cells and reduces monocyte recruitment (Hofbauer et al., 1999). EGCG-mediated inhibition of chemokine 
production and chemokine interactions with their receptors on white blood cell surface may alter the range and magnitude of the inflammatory response including white blood cell count and pattern (Forester, Lambert, 2011).

Our findings showed that 6-week GTE supplementation resulted in a significant increase in the absolute eosinophil count as well as eosinophil percentage in both study groups. An increase in eosinophil count in healthy individuals may be induced by non-allergic mechanisms (Jacobsen, Helmers, Lee, Lee, 2012) and a variety of agents (including EGCG) that interrupt eosinophil adhesion to the vascular endothelium (Blanchard, Rottenberg, 2008). Considering the fact that EGCG decreases VCAM-1 expression, it might be speculated that post-supplementation increase in eosinophil count was associated with changes in interaction and enhanced eosinophil recruitment from the marginal to the circulating pool.

Jacobsen et al. (2012) demonstrated that eosinophils were important regulators of local immunity and remodeling/repair (see below) and might play a role in maintaining metabolic homeostasis. Remodeling and repair are associated with physical training-related changes in cell structure and function; the processes may also be induced by thermogenic supplements enhancing adipose tissue metabolism (Mraz, Haluzik, 2014; Sadowska-Krępa, Pokora, Podgórski, Obara, Domaszewski, 2015; Pokora, Sadowska-Krępa, Żak, Domaszewski, 2016). The results of clinical and animal studies indicate a potential role of eosinophils in maintaining metabolic homeostasis and activation of adipose tissue macrophages (Kim, Plutzky, 2016). Although we observed a significant GTE supplementation-related increase in eosinophil count, the absolute number of this blood cell subpopulation was within standard reference ranges $\left(0.100-0.600 \times 10^{9} / \mathrm{l}\right)$ and did not exceed a count of over $0.600 \times 10^{\%} / \mathrm{l}$, which is generally considered eosinophilia in adults.

Summing up, it should be noted that long-term GTE supplementation in CrossFit-trained men did not result in significant changes in body weight and composition and the total white blood cell count. However, the percentage of peripheral blood eosinophils increased while monocyte and neutrophil counts decreased. The changes in white blood cells were less pronounced in CrossFit-trained compared to control participants.

\section{References}

Bayer, D., Jansen, J., Beltz, L. (2012). Differential effects of tea extracts on growth and cytokine production by normal and leukemic human leukocytes. Functional Foods in Health and Disease, 2 (4), 72-85.

Benzie, I., Szeto, Y., Strain, J. (1999). Consumption of green tea causes rapid increase in plasma antioxidant power in humans. Nutr Cancer, 34, 83-7. DOI: 10.1207/S15327914NC340112.

Blanchard, C., Rothenberg, M. (2009). Biology of the eosinophil. Adv Immunol, 101, 81-121. DOI: 10.1016/S0065-2776(08)01003-1.

Dona, M., Dell'Aica, I., Calabrese, F., Benelli, R., Morini, M., Albini, A., Garbisa, S. (2003). Neutrophil restraint by green tea: inhibition of inflammation, associated angiogenesis, and pulmonary fibrosis. J Immunol, 170, 4335-4341.

Forester, S., Lambert, J. (2011). Antioxidant effects of green tea. Mol Nutr Food Res, 55 (6), 844-854. DOI: 10.1002/mnfr.201000641.

Gleeson, M. (2007). Immune function in sport and exercise. J Appl Physiol, 103, 693-699. DOI: 10.1152/japplphysiol.00008.2007.

Han, S., Toborek, M., Hennig, B. (2012). EGCG protects endothelial cells against PCB 126-induced inflammation through inhibition of AhR and induction of Nrf2-regulated genes. Toxicol Appl Pharmacol, 261 (2), 181-188. DOI: 10.1016/j.taap.2012.03.024.

Hofbauer, R., Frass, M., Gmeiner, B., Handler, S., Speiser, W., Kapiotis, S. (1999). The green tea extract epigallocatechin gallate is able to reduce neutrophil transmigration through monolayers of endothelial cells. Wien Klin Wochenschr, 111, 278-282.

Horn, P., Pyne, D., Hopkins, W., Barnes, C. (2010). Lower white blood cell counts in elite athletes training for highly aerobic sports. Eur J Appl Physiol, 110, 925-932. DOI: 10.1007/s00421-010-1573-9.

Howley, E.T., Bassett, D.R., Welch, H.G. (1995). Criteria for maximal oxygen uptake: review and commentary. Med Sci Sports Exerc, 27 (9), 1292-1301. 
Hulmi, J., Myllymäki, T., Tenhumäki, M., Mutanen, N., Puurtinen, R., Paulsen, G., Mero, A. (2010). Effects of resistance exercise and protein ingestion on blood leukocytes and platelets in young and older men. Eur J Appl Physiol, 109 (2), 343-353. DOI: 10.1007/ s00421-010-1360-7.

Jacobsen, E.A., Helmers, R.A., Lee, J.J., Lee, N.A. (2012). The expanding role(s) of eosinophils in health and disease. BLOOD, 120 (19), 3882-3890. DOI: 10.1182/blood-2012-06-330845.

Kim, S.H., Plutzky, J. (2016). Brown fat and browning for the treatment of obesity and related metabolic disorders. Diabetes Metab J, 40, 12-21. DOI: 10.4093/dmj.2016.40.1.12.

Kim, S.H., Quon, M.J., Kim, J.A. (2014). New insights into the mechanisms of polyphenols beyond antioxidant properties; lessons from the green tea polyphenol, epigallocatechin 3-gallate. Redox Biology, 2 (1), 187-195. DOI: 10.1016/j.redox.2013.12.022.

Kliszczewicz, B., Quindry, C.J., Blessing, L.D., Oliver, D.G., Esco, R.M., Taylor, J.K. (2015). Acute Exercise and Oxidative Stress: CrossFit( ${ }^{\mathrm{TM}}$ ) vs. Treadmill Bout. J Hum Kinet, 47, 81-90. DOI: 10.1515/hukin-2015-0064.

Krüger, K., Mooren, F.C. (2014). Exercise-induced leukocyte apoptosis. Exerc Immunol Rev, 20, 117-134.

Lambert, J., Elias, R. (2010). The antioxidant and pro-oxidant activities of green tea polyphenols: a role in cancer prevention. Arch Biochem Biophys, 501 (1), 65-72. DOI: 10.1016/j.abb.2010.06.013.

Ludwig, A., Lorenz, M., Grimbo, N., Steinle, F., Meiners, S., Bartsch, C., Stangl, K., Baumann, G., Stangl, V. (2004). The tea flavonoid epigallocatechin-3-gallate reduces cytokine-induced VCAM-1 expression and monocyte adhesion to endothelial cells. Biochem Biophys Res Commun, 316, 659-665. DOI: 10.1016/j.bbrc.2004.02.099.

Majkova, Z., Smart, E., Toborek, M., Hennig, B. (2009). Up-regulation of endothelial monocyte chemoattractant protein-1 by coplanar PCB77 is caveolin-1-dependent. Toxicol Appl Pharmacol, 237, 1-7. DOI: 10.1016/j.taap.2009.02.016.

McKay, D., Blumberg, J. (2002). The role of tea in human health: An update. J Am Cool Nutr, 21, 1-13.

Mraz, M., Haluzik, M. (2014). The role of adipose tissue immune cells in obesity and low-grade inflammation. J Edocrinol, 222 (3), R113-R127. DOI: 10.1530/JOE-14-0283.

Metrikat, J., Albrecht, M., Maya-Pelzer, P., Ortlepp, J.R. (2009). Physical fitness is associated with lower inflammation, even in individuals with high cholesterol - An alternative to statin therapy? CVD Prevention and Control, 4 (3), 149-156. DOI: http:// dx.doi.org/10.1016/j.cvdpc.2009.05.001.

Michishita, R., Shono, N., Inoue, T., Tsuruta, T., Node, K. (2010). Effect of exercise therapy on monocyte and neutrophil counts in overweight women. Am J Med Sci, 339, 152-156. DOI: 10.1097/MAJ.0b013e3181c6a980.

Mizolf, M., Szymusiak, H., Wiglo, A., Reitjers, I., Tyrakowska, B. (2008). pH-Dependent Radical Scavenging Capacity of Green Tea Catechins. J Agric Food Chem, 56, 816-823.

Mooren, F.C., Lechtermann, A., Völker, K. (2004). Exercise-induced apoptosis of lymphocytes depends on training status. Med Sci Sports Exerc, 36 (9), 1476-1483.

Mooren, F.C., Völker, K., Klocke, R., Niko, I.S., Waltenberger, J., Krüger, K. (2012). Exercise delays neutrophil apoptosis by a G-CSFdependent mechanism. J Appl Physiol, 113 (7), 1082-1090.

Natale, V.M., Brenner, I.K., Maldoveanu, A.I., Vasiliou, P., Sheik, P., Shephard, R.J. (2003). Effects of three different types of exercise on blood leukocyte count during and following exercise. Sao Paulo Med J/Rev Poul Med, 121 (1), 9-14.

Orysiak, J., Witek, K., Żmijewski, P., Gajewski, J. (2012). White Blood Cells in Polish Athletes of Various Sports Disciplines. Biol. Sport, 29, 101-105. DOI: 10.5604/20831862.988883.

Osada, K., Takahashi, M., Hoshina, S., Nakamura, M., Nakamura, S., Sugano, M. (2001). Tea catechins inhibit cholesterol oxidation accompanying oxidation of low density lipoprotein in vitro. Comp Biochem Physiol C Toxicol Pharmacol, 128, 153-64.

Pae, M., Wu, D. (2013). Immunomodulating effects of epigallocatechin-3-gallate from green tea: mechanisms and applications. Food Funct, 4 (9), 1287-1303. DOI: 10.1039/c3fo60076a.

Pokora, I., Żak, A., Pokora, P. (2015). Effect of exercise-induced physiological strain on blood cortisol level and peripheral blood leukocytes in trained and untrained men. Scientific Review of Physical Culture, 5 (4), 118-124.

Pokora, I., Sadowska-Krępa, E., Żak, A., Domaszewski, P. (2016). Wpływ suplementacji wyciągiem z zielonej herbaty na odpowiedź metaboliczną i termogenną podczas wysiłku fizycznego u trenujących mężczyzn. Probl Hig Epidemiol, 97 (1), 81-86.

Pyne, D.B., Gleeson, M. (1998). Effects of intensive exercise training in immunity in athletes. Int J Sports Med, 19, S183-S194. DOI: 10.1055/s-2007-971991.

Qin, S., Alcorn, J.F., Craigo, J.K., Tjoeng, Ch., Tarwater, P.M., Kolls, J.K., Reinhart, J.A. (2011). Epigallocatechin-3-Gallate Reduces Airway Inflammation in Mice through Binding to Proinflammatory Chemokines and Inhibiting Inflammatory Cell Recruitment. J Immunol, 186, 3693-3700. DOI: 10.4049/jimmunol.1002876. 
Sadowska-Krępa, E., Pokora, I., Podgórski, T., Obara, P., Domaszewski, P. (2015). Wpływ suplementacji ekstraktem z zielonej herbaty na profil lipidowy krwi w warunkach spoczynkowych i powysiłkowych. Probl Hig Epidemiol, 96 (3), 671-676.

Saleh, F., Raghupathy, R., Asfar, S., Oteifa, M., Al-Saleh, N. (2014). Analysis of the effect of the active compound of green tea (EGCG) on the proliferation of peripheral blood mononuclear cells. BMC Complement Altern Med, 30 (14), 322. DOI: 10.1186/1472-6882-14-322.

Takano, F., Tanaka, T., Aoi, J., Yahagi, N., Fushiya, S. (2004). Protective effect of (+)-catechin against 5-fluorouracil-induced myelosuppression in mice. Toxicology, 201 (1-3), 133-142. DOI: 10.1016/j.tox.2004.04.009.

Vattem, D.A., Maitin, V. (2016). Functional Foods, Nutraceuticals and Natural Products: Concepts and Applications. Lancaster: DEStech Publications Inc.

Walsh, N., Gleeson, M., Shephard, R.J., Gleeson, M., Woods, J.A., Bishop, N.C., Fleshner, M., Green, C., Pedersen, B.K., Hoffman-Goetz, L., Rogers, C.J., Northoff, H., Abbas, I.A., Simon, P. (2011). Position statement. Part one: Immune function and exercise. Exerc Immunol Rev, 17, 6-63.

Yin, S.T., Tang, M.L., Su, L. (2008). Effects of Epigallocatechin- 3-gallate on lead-induced oxidative damage. Toxicology, 249, 45-54. DOI: 10.1016/j.tox.2008.04.006.

Zhu, W., Xu, J., Ge, Y., Cao, H., Ge, X., Luo, J., Xue, J., Yang, H., Zhang, S., Cao, J. (2014). Epigallocatechin-3-gallate (EGCG) protects skin cells from ionizing radiation via heme oxygenase-1 (HO-1) overexpression. J Radiat Res, 55 (6), 1056-1065. DOI: 10.1093/ jrr/rru047.

Cite this article aS: Żak, A., Pokora, I. (2017). Effect of Long-Term Green Tea Extract Supplementation on Peripheral Blood Leukocytes in CrossFit-Trained and Untrained Men. Central European Journal of Sport Sciences and Medicine, 19 (3), 67-76. DOI: 10.18276/ cej.2017.3-06. 